\title{
Some Properties of a Strain of Cucumber Mosaic Virus Isolated from Chickpea in India
}

T. V. CHALAM, Research Scholar, International Crops Research Institute for the Semi-Arid Tropics (ICRISAT), Patancheru P.O. 502 324, Andhra Pradesh, India; M. V. REDDY, Chickpea Pathologist, International Centre for Agricultural Research in the Dry Areas, Aleppo, Syria; Y. L. NENE, Program Leader, S. P. S. BENIWAL, Senior Plant Pathologist, Pulses Improvement Program. ICRISAT; and J. SUBBAYYA. Professor of Plant Pathology, S. V. Agricultural College. Tirupati 507 502. Andhra Pradesh, India

\begin{abstract}
Chalam. T. V.. Reddy, M. V., Nene, Y. L., Beniwal, S. P. S., and Subhayya, I. 1986. Some propertics of a strain of cucumber mosaic virus isolated from chickpea in India. Plant Discase $70: 128-130$.

A virus isolated in India from chick pea plants showing tip necrosis and mosaic was identified as a strain of cucumber mosiac virus on the basis of host range, in vitro properties. insect transmission. electron microscopy, and serology. The purified virus had a sedimentation cocfficient of $104 \mathrm{~S}$ and a buoyant density of $1.325 \mathrm{~g}$ ml. The polyacrylamide gel electrophoresis (PAGE) of virus coat protein revealed the presence of a single polypeptide with a molecular weight of 25.000 ). The P'A(iE of virus RNA revealed the presence of four RNA species. An antiscrum to the virus produced in rabbit had a titer of 1 1.024 in double-diffusion tests.
\end{abstract}

Chickpea (Cicer arielinum) is an important grain legume crop in dryland agriculture in Asia. Africa, and Central and South America. Six viruses that naturally infect chickpea have been reported from different parts of the world (12). These include alfalfa mosaic virus (13), bean yellow mosaic virus $(6,8)$. cucumber mosaic virus (CMV) $(5,9)$. lettuce necrotic vellows virus (4), pea leafroll virus $(8,13,14)$, and pea enation mosaic virus (6). From India, only a brief report on the natural occurrence of CMV was published (5). Our study describes the purification and properties of a CMV isolate from naturally infected chickpea in India.

\section{MATERIALS AND METHODS}

The virus was isolated from a chickpea plant grown in the fields of the Genetic Resources Unit at ICRISAT Center that was showing lip necrosis and mosaic. It was maintained by periodic sap inoculation under greenhouse conditions on a local kabuli (white-seeded) chickpea

Present address of first author: Subject Matter Specialist (Plamt Protection). Regional Agricultural Research Station. Palem 509215 . Andhra Pradesh. India.

Part al Ph.l). thesis submitted by the first atuthor to Andhra Pradesh Agricultural L niversity, Hyderabad 5000.30 . Andhra Pradesh. India

Authoried for publication as IC RISAl Journal Article No. 417

Accepted for publication 12 July 1985

The publication costs of this article were defrayed in part by page charge payment. This articie must therefore be
hereby marked "advertisement" in accordance with 18 U.S.C. $\$ 1734$ solely to indicate this fact.

1986 The American Phytopathological Society varicty obtained from the local market.

Transmission. The inoculum was prepared by grinding infected chickpea leaves with a prechilled pestle and mortar in $0.05 \mathrm{M}$ potassium phosphate buffer. $\mathrm{pH} 7.5$, containing $0.01 \mathrm{M}$ each of sodium sulfite and sodium diethyldithiocarbamate $(1: 4, w)$. Celite $(1 \%, w)$ was added to the extract and rubbed onto the leaves of test plants with the broad end of the pestle. Four plants of each species were sap-inoculated with the virus. An equal number of plants inoculated with healthy sap were kept as controls.

For insect transmission, two aphid species. Myzus persicae and Aphis craccivora, were used. After a starvation period of $1 \mathrm{hr}$, the aphids were allowed to probe on infected chick pea plants for I min. They were then transferred onto healthy chick pea plants for an inoculation feeding period of 12-14 hr after which they were killed by spraying $0.02 \%$ dimethoate. Five to 10 aphids were used per plant.

Persistence of infectivity in expressed sap. Physical properties of the virus were determined in infected chickpea sap following the procedure described by Bos et al (3). Chenopodium amaranticolor was used as an assay host.

Virus purification. The virus was purified from systemically infected chickpea plants $(7-10$ days after inoculation). Entire plants except roots were used for purification. The homogenization, preliminary clarification, and pelleting of the virus were done according to the procedure described by Tomlinson et al (15). However, further purification was achieved by precipitating the virus with polyethylene glycol (PEG 6000 . Carbowax, Fisher Scientific) followed by
10-40\% sucrose density-gradient centrifugation $(100,000 \mathrm{~g}$ for $90 \mathrm{~min})$. Gradients were prepared in $0.025 \mathrm{M}$ potassium phosphate buffer containing 1 $\mathrm{mM}$ EDTA. The light-scattering zone was removed and diluted with the same buffer, then one cycle of differential centrifugation $(10,000 \mathrm{~g}$ for $10 \mathrm{~min}$ and $105,000 \mathrm{~g}$ for $2 \mathrm{hr}$ ) was given. The same buffer was used for suspending the virus pellet.

Electron microscopy and spectrophotometry. Purified virus preparations were stained with $1 \%$ aqueous uranyl acetate, $\mathrm{pH} 4.2$, and examined under a Philips 201C electron microscope. The average diameter of the virus particles was calculated by measuring 100 particles with a $\times 7$ Bausch \& Lomb magnifier directly from electron micrograph negatives.

The UV-absorption spectra of the purified virus were recorded in a spectrophotometer. The virus concentrations were estimated by spectrophotometry using the extinction coefficient reported for CMV (7).

Equilibrium density-gradient centrifugation. The virus in $1 \mathrm{ml}$ of suspending medium was layered over $4 \mathrm{ml}$ of $40 \%$ cesium chloride (density $=1.42 \mathrm{~g} / \mathrm{ml}$ ) prepared in the same buffer in $5 \mathrm{ml}$ polyallomer tubes and entrifuged in a $S W 50$ rotor at $200,000 \mathrm{~g}$ for $18-20 \mathrm{hr}$ at 4 $C$. The bottom of the gradient tube was punctured and $0.2-\mathrm{ml}$ fractions were collected. These fractions were monitored in the Beckman spectrophotometer at 260 $n m$, and the densities of the fractions were determined by their refractive indices measured with an Abbe refractometer.

Analytical ultracentrifugation. The purified virus, suspended in $0.025 \mathrm{M}$ potassium phosphate buffer, $\mathrm{pH} 7.5$, was centrifuged at $30.000 \mathrm{rpm}$ in a Spinco model $E$ analytical ultracentrifuge. After reaching the desired speed, the Schleiren pattern was photographed at 3 -min intervals.

Polyacrylamide gel electrophoresis (PAGE). The PAGE of CMV-coat protein and RNA were performed following the methods of Laemmli (10) and Adesnik (1), respectively.

Serology. The virus was identified by Ouchterlony agar double-diffusion test (2) and enzyme-linked immunosorbent 
assay (ELISA) (11), using antisera to CMV-C (obtained from H. A. Scott, University of Arkansas); CMV-S and CMV-Ix (obtained from H. E. Waterworth, USDA, Beltsville, MD); and U-CMV, X-CMV, Q-CMV, M$C M V$, and T-CMV (obtained from R. 1 . B. Francki, University of Adelaide, Australia).

A rabbit was injected intramuscularly (four times at 10-day-intervals) with purified CMV (1 ml containing 2-3 $\mathrm{mg}$ of virus) emulsified with an equal volume of Freund's incomplete adjuvant. Ten days after the last injection, the blood was collected from the marginal ear vein and allowed to clot, then serum was separated. The titer of the antiserum was determined by the agar double-diffusion tests (2).

\section{RESULTS}

Symptomatology and host range. Two types of symptoms were produced by CMV in chickpea. In certain varieties, drooping of the terminal bud occurred 4-5 days after inoculation (Fig. IA). followed by necrosis of terminal and axillary buds and wilting of plants. Plants died 9-10 days after inoculation. In other varieties, inoculated plants did not wilt after showing drooping and necrosis of the terminal bud but showed chlorosis followed by proliferation of branches. Affected plants bore very small leaves and appeared bushy (Fig. IB). The virus was readily transmitted mechanically from chickpea to various plant species, producing chlorotic local lesions on Tetragonia expansa Murr., Cucurbita pepo L., and Datura stramonium L.; necrotic local lesions on Chenopodium amaranticolor Coste \& Reyn., C. murale L., Cajanus cajan (L.) Millsp., Phaseolus vulgaris L. 'Porrillo,' 'Red Kidney, 'Pinto,' 'Monroe,' and 'Lavica,' Vicia faba L. 'Early Long Pod,' Vigna unguiculata (L.) Walp. susp. unguiculata 'Early Ramshorn,' 'Barsati mutant,' and 'Pusa Dophasli'; mosaic mottling on Nicotiana tabacum L. 'Xanthi-nc' and $N$. rustica L. 'White Pathar'; and systemic chlorotic patches on Cucumis sativus L. No symptoms developed on Gomphrena globosa L., Chrysanthemum sp., Arachis hypogaea L., Canavalia ensiformis DC., Macrotyloma uniflorum (Lam.) Verdc., Capsicum annuum L., Lycopersicon esculentum Mill. 'Pusa Ruby,' and Petunia hyrida Vilm. We have not ruled out the possibility of these no-symptom species serving as latent hosts.

Aphid transmission. The virus was transmitted by Myzus persicae and Aphis craccivora, which was a more efficient vector.

Serology. The virus reacted positively with antisera to CMV-S when tested by double-diffusion test (Fig. 2) and ELISA. The virus also reacted with antisera to other strains of CMV: CMV-C, CMV-Ix, $\mathrm{U}-\mathrm{CMV}, \mathrm{X}-\mathrm{CMV}, \mathrm{Q}-\mathrm{CMV}, \mathrm{M}-\mathrm{CMV}$, and T-CMV. The antiserum produced in rabbit to the chickpea strain of CMV had a titer of $1 / 1,024$ as determined by the double-diffusion test. No reaction was noted with healthy sap.

Properties of the virus. In chickpea sap, the virus had a thermal inactivation point between 70 and $75 \mathrm{C}$, a dilution end point between $10^{-3}$ and $10^{-4}$, and longevity between 4 and 5 days. Isometric particles about $30 \mathrm{~nm}$ in diameter were observed under the electron microscope (Fig. 3). Yields of virus averaged 80-100 $\mathrm{mg} / \mathrm{kg}$ of tissue. The absorption spectrum of purified virus was found to be typical of nucleoprotein with an absorption maximum at $260 \mathrm{~nm}$ and minimum at $240 \mathrm{~nm}$. It had an $A_{200 \cdot 280}$ value of 1.55 (uncorrected for light scattering).

Purified virus had a sedimentation coefficient and buoyant density of $104 \mathrm{~S}$ and $1.325 \mathrm{~g} / \mathrm{ml}$, respectively. The PAGE of CMV-coat protein revealed the presence of a single polypeptide that had a molecular weight of 25,000 based on the linear relationship between migration of markers and the logarithm of their known molecular weights. The PAGE of CMV-RNA revealed the presence of four RNA species.

\section{DISCUSSION}

CMV was found to infect chickpeas
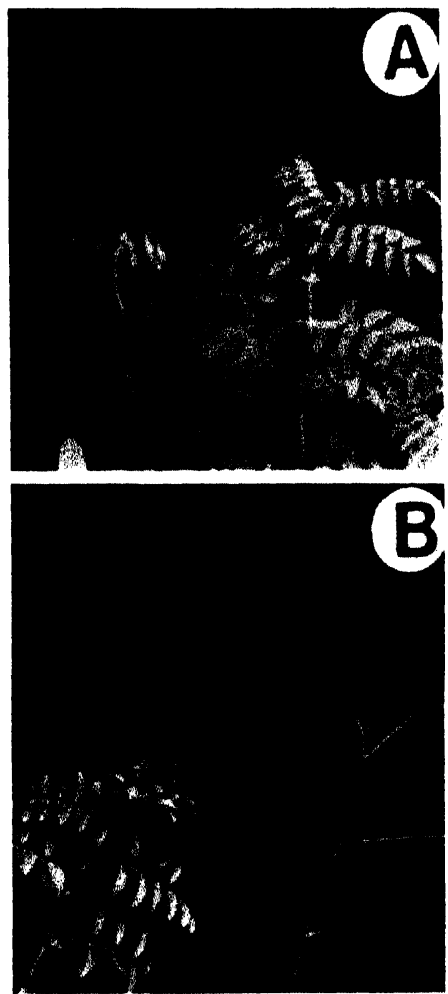

Fig. 1. Symptoms produced by cucumber mosaic virus on chickpea: (A) (Left) Drooping of the terminal bud in infected plant: (right) healthy plant. (B) (Left) Proliferation and bushiness of branches with small leaves in infected plant; (right) healthy plant. under natural conditions. Its identity was confirmed by serology, host range, in vitro properties, insect transmission, particle morphology, and physicochemical properties. The present strain of CMV produced necrotic local lesions on different cultivars of bean and cowpea similar to most of the reported strains, but it produced systemic chlorotic patches on cucumber instead of mosaic and also it did not infect $L$. esculentum. Waterworth and Povish (16) reported a strain of CMV from Ixora (CMV-Ix) that behaved similarly. On certain varieties of chickpea, the present strain of CMV caused stunting and bushiness, which are similar to one described by Kaiser and Danesh (8) from lran. Dhingra et al (5) observed excessive axillary shoots bearing very small, slightly chlorotic leaves on chickpea inoculated with CMV. Similar symptoms were observed with the present strain of CMV, except that the new small leaves remained green. The

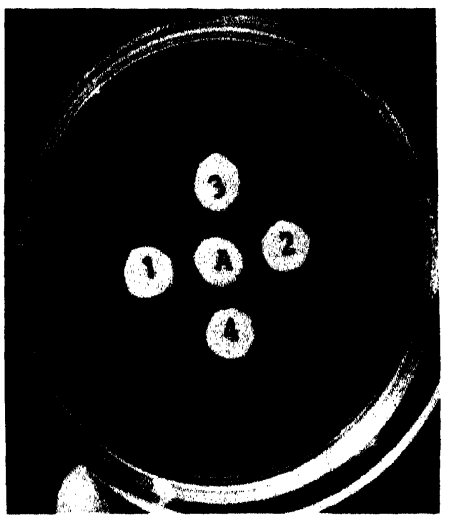

Fig. 2. Agar gel double-diffusion test with purified cucumber mosaic virus (CMV) and infective crude sap. Contents of outer wells: 1 = sap from CMV-infected chickpea, $2=$ purified $C M V, 3=$ buffer, and $4=$ sap from healthy chickpea (4). The center well (A) contains antiserum to CMV-S. Note a positive reaction of purified $C M V$ and infective sap with antiserum

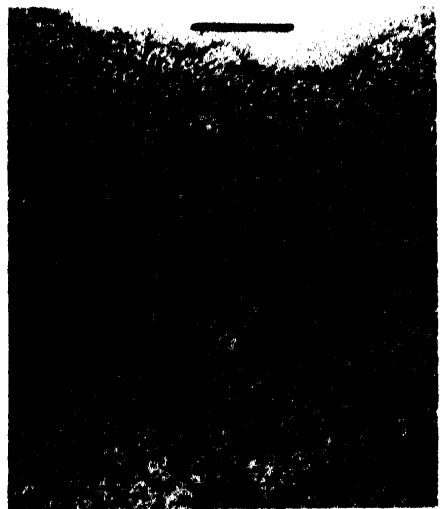

Fig. 3. Electron micrograph of purified cucumber mosaic virus after staining with $1 \%$ uranyl acetate. Scale bar $=100 \mathrm{~nm}$. 
inability of the present strain of CMV to infect peanut and chrysanthemum indicates that it is not peanut stunt virus or tomato aspermy virus, which are other members of the cucumovirus group.

The natural occurrence of this virus on chickpea in India was found to be less than $1 \%$. However, considering the cropping pattern in India, which includes several cucurbitaceous and leguminous plants that not only harbor CMV but also aid in the buildup of aphid vector, this virus has the potential to become widespread on chickpea in future.

\section{ACKNOWLEDGMENTS}

We thank H. A. ScotI, University of Arkansas, H E. Waterworth, USDA, Beltsville, MD, and R. I. B Francki, IIniversity of Adclaidc, Australia, for supply of antisera to CMV. The first author acknowledges the receipt of financial assistance from ICRISAT.

\section{LITERATURE CITED}

1. Adesnik. M. 1970. Polyacrylamide gel electro- phoresis of viral RNA. Pages 125-177 in Methods in Virology. Vol. 5. K. Maramorosch and H. Koprowski, eds. Academic Press. New York.

2. Ball, E. M. 1974. Serological tests for the identification of plant viruses. Am. Phytopathol. Soc., St. Paul, MN. 31 pp.

3. Bos, L.. Hagedorn. D. J., and Quantz. L. 1960 Suggested procedures for international identification of legume viruses. Tijdschr. Plantennekten 66:328-343.

4. Corbin, E. J. 1975. Present status of chickpea research in Australia. Pages $87-94$ in: Proceedings, International Workshop on Grain Legumes. ICRISAI, Hyderabad, India.

5. Dhingra, K. I... Chenulu, V. V., and Verma, A. 1979. A leaf reduction disease of Cicer arietinum in India, caused by a cucumovirus. (urr. Sci. 48:486-488.

6. Erwin, D. C., and Snyder, W. C. 1958. Yellowing of garbanzo beans. Calif. Agric. 12:6,16.

7. Francki, R. I. B., Mossop, D. W., and Hatta, T 1979. Cucumber mosaic virus. Descriptions of Plant Viruses. No. 213. Commonw. Mycol. Inst. Assoc. Appl. Biol., Kew, Surrey, England $6 \mathrm{pp}$.

8. Kaiser, W. J., and Danesh, D. 197I. Biology of four viruses affecting (icer arietinum in Iran Phytopathology 61:372-373.

9. Kaisc, W. J., Danesh. D.. Okhovat. M.. and
Mossahebi, H. 1968. Diseases of pulse crops (edible legumes) in Iran. Plant Dis. Rep. 52:687-691.

10. Laemmli, U. K. 1970. Cleavage of structural proteins during the assembly of the head of bacteriophage 14. Nature (London) 227:680-685.

II. Lister, R. M. 1978. Application of the enzymelinked immunosorbent assay for detecting viruses in soybean seed and plants. Phyto. pathology 68:1393-1400.

12. Nene, Y. L. 1980. A world list of pigeonpea (Cajanus cajan (L.) Millsp.) and chickpea (Cicer arietinum L.) pathogens. ICRISAT Pulsc Pathol. Prog. Rep. 8, Patancheru, A.P., India. 14 $\mathrm{pp}$.

13. Nene, Y. L., Haware, M. P., and Reddy, M. V 1978. Diagnosis of some wilt-like disorders of chickpea (Cicer arietinum (.). Inf. Bull. 3. ICRISAT, Patancheru, A.P., India. 44 pp.

14. Nene, Y. L.., and Reddy, M. V. 1976. Preliminary information on chickpea stunt. Trop. (irain Legume Bull. 5:31-32.

15. Tomlinson, J. A.. Shepherd, R. J., and Walker. J. C. 1958. Purification and serology of cucumber mosaic virus. Nature (london) 182:1616.

16. Waterworth, H. E., and Povish, W. R. 1975. A virus related to cucumber mosaic virus isolated trom imported Ixora plant. Phytopathology 65:728-729. 